\title{
INFLUENCE OF NEUROTROPIC AND METABOLIC DRUGS ON STRUCTURAL AND FUNCTIONAL STATE OF LIPID MATRIX OF THE CELL MEMBRANE
}

M. V. SEBA, Candidate of Agricultural Sciences, Associate Professor of Genetics, Breeding and Reproductive Biotechnology department https://orcid.org/0000-0001-9696-934X

E-mail: nikolay_seba@ukr.net

M. О. КНОMENKO, Candidate of Agricultural Sciences, assistant of Genetics, Breeding and Reproductive Biotechnology department

E-mail: marina.homenko@ukr.net https://orcid.org/0000-0001-7023-3676

D. K. NOSEVYCH, Candidate of Agricultural Sciences, Associate Professor of Dairy and Beef Production Technology department

https://orcid.org/0000-0003-2495-2084

E-mail:dknosevich@i.ua

National University of Life and Environmental Sciences of Ukraine

M. I. GOLUBEV, Candidate of Agricultural Sciences, Associate Professor, Deputy Director of the Department of Attestation of Higher Qualifications

E-mail:holubiev@nubip.edu.ua https://orcid.org/0000-0002-6647-4335

Ministry of Education and Science of Ukraine

V. G. KAPLUNENKO, director

E-mail: kaplunenkov@gmail.com

Nanomaterials and Nanotechnologies Ltd.

I. V. BYELINSKA, Senior Researcher, Educational and Scientific Center Institute of Biology and Medicine

E-mail: byelinska@univ.kiev.ua

https://orcid.org/0000-0003-3551-1161

V. K. RYBALCHENKO, Doctor of Biological Sciences, Professor, Educational and Scientific Center Institute of Biology and Medicine https://orcid.org/0000-0001-5069-2621

Taras Shevchenko National University of Kyiv

\begin{abstract}
Lately, more and more often to stimulate the reproductive function of animals people use biochemical products, which are based on neurotropic and metabolic compounds and trace elements of nanobiotechnological origin. In order to new biotechnical drugs search and development, and more effective and safe combinations of dietary supplements in them, one should know Biochemical mechanisms
\end{abstract}


of membranotropic action of these substances on a cell. Since these substances can lead to physiological changes in the cell and trigger nonspecific toxic effects on the body of animals depending on dose and period of action. The article presents the results of studies on the effects of neurotropic and metabolic drugs on structural and functional state of lipid matrix of the cell membrane. In experiment were used four drugs: hlutam 1-M (Sodium Glutaminate), stymulin (Sodium Glutaminate, Sodium Succinate), nanovulin-VHR (Sodium Glutaminate, Sodium Succinate, Copper Citrate), nanovulin- $R$ (Sodium Glutaminate, Sodium Succinate, L-arginine, Copper Citrate). The main task of the experiment was to investigate the concentration effects and primary mechanisms of membranotropic influence of the components of investigated drugs in the range of physiological concentrations of the active substance on the structural and functional state of the lipid matrix of cell membranes. According to research results, it was found that Sodium Glutaminate, which is part of all the investigational drugs, affects the polarity of the hydrophobic zone of the membrane and increases the polarity of the lipid surround. An application of Sodium glutaminate with Succinate in same drug (stimulin, nanovulin-VHR, nanovulin- $R$ ) reduces the destructive effects of Sodium Glutamate on the lipid membrane of cells. Also, it should be noted that Copper Citrate in combination with Glutaminate and Succinate (nanovulin-VHR, nanovolin-R) excludes the membrane-stabilizing and membrane-disruptive effects of their influence on the structure of lipid packing in the bilayer. From the results of the research we can suggest, that aquachelates penetrate the hydrophobic lipid bilayer zone, as evidenced by the total fluorescence quenching of pyrene.

Keywords: Glutaminate, Succinate, nanovulin, Copper, membranes, citrate.

\section{Introduction.}

For a long time it was considered that biologically active substances (BAS) have their own influence on a cell just by interaction with specific membrane protein-receptors, resulting in released energy of chemical signal of Sodium Glutaminate decoded and transformed into specific biological effects. For each such event cells have many secondary messengers that act as trigger element in the chain mechanisms between detector and effector cellular structures (Gennis, 1997; Kukhar et al., 1992). However, in recent years, were found that dietary supplements (especially substances of xenobiotic nature) can change the functional activity of cells due to mechanisms that do not involve the straight binding with protein receptors (Gruntkovsky et al., 2015; Rybalchenko et al., 1999; Bychko et al., 2016).

The peculiarity of such non-receptor interactions is the dependence on the physico-chemical nature of BAS and their ability to vary in a way to the structural and functional state of the lipid matrix, which is thus specific receptors (Ostrovska, 2004). These effects affect the dose and time of the substance, in addition to physiological changes in cell functions, a number of dietary supplements can also initiate induction of nonspecific toxic effects. In this regard, the need for detailed experimental studies that provide a complete understanding of the primary mechanisms of interaction between dietary supplements and membrane structures are obvious. 


\section{Analysis of recent research and publications.}

Recently, an intensive development of a new concept of biological action of biotechnological drugs created using neurotrophin and metabolic compounds and trace elements of nanobiotechnological origin on immuno-biochemical and morphological parameters of the metabolism of the reproductive system and the organism of animals, as well as on indicators of reproductive ability, when applied during reproductive cycle. Many scientific studies have been carried out on the development and use of aminoacids based biologically active drugs. A special place amongst which is given to glutamic acid, which causes neurotropic action, because it is one of the main energy metabolites in the nerve tissue.

Glutamic acid plays a significant role in the regulation of bioenergetic processes occurring in the nervous system due to direct involvement in glycolysis reactions, gluconeogenesis, ketone body synthesis and glycogen formation (Kositsyn, 2004). Glutamic acid can be included in the metabolic processes in certain organs or systems of the body depending on the functional load they perform at a certain point. As the only amino acid that is oxidized in the brain tissues and serves as an energy source for the activity of the neurons, it has a stimulating effect on the hypothalamic-pituitary system (Sheremete et al, 2017).

Based on glutamic acid, biologically active drugs such as glutam, glutam $1 \mathrm{M}$, stimulin-vet, which are environmentally friendly and easily manufactured both in laboratory conditions and in production, were created. The active substance of these drugs is Sodium Glutaminate. Influence on the organism of animals occurs through neuroendocrine regulation, which increases the enzyme activity in cells, stimulating the metabolism (Tishchenko \& Sheremeta, 2006; Lancey \& Lee, 1993).

The glutam drug, applied to cows under the skin on the 6-8th day of the sexual cycle, is likely to increase fertility by $17.9 \%$, and its administration by 13-15 days - by $13.7 \%$ compared to the control (Rybalchenko \& Ostrovskaya, 1998; Prylutskyy et al., 2016). In addition to the stimulation of reproductive capacity, after the use of glutam, there is a tendency to increase by $0.1-0.15$ and $0.04 \%$ fat and protein content in milk of cows (Seba, 2005).

Injection of glutam $1 \mathrm{M}$ for two consecutive days in the tail fold with a total dose of $40 \mathrm{ml}$ at the 6-7th day after the first insemination leads to an increase in fertility by $20 \%$, and after the second and more - by $11.4 \%$ (Tishchenko \& Sheremeta, 2006 ) An increase in the dose of the drug up to $60 \mathrm{ml}$ and its introduction on the 6-8th day after the first artificial insemination leads to a significant increase in fertility by $26.6 \%$ (Sheremeta $\&$ Seba, 2004). And the administration for three consecutive days under the skin of cows, glutam $1 \mathrm{M}$ in a dose of $20 \mathrm{ml}$ at intervals between 3-6 days postpartum period contributes to a possible increase in fertility by $15.2-17.5 \%$ (Tishchenko \& Sheremeta, 2006).

Based on the drug stimulin-vet a new dietary supplement nanovolin-VHR was created. The researchers found that applying the drug to cows 12 and 24 hours after the first insemination contributed to an increase in the number of cows with ovarian follicles and a decrease in the number of females with anovulatory cycle (Gruntkovsky, 2015).

The applying of stimulin-vet and nanovulin-VHR into cattle in 12 and 24 hours after insemination promotes fer- 
tilization of cows by 22.2 and $22.3 \%$. During the appluing of these drugs for the second day of the sexual cycle, the level of insulin in blood serum increases by $39.9 \%$ and $50.3 \%$ respectively and on the 7 th day - progesterone by $29.8 \%$ and $28.1 \%$ respectively. In blood serum of heifers, which were twice injected with nanovulin-VHR on the 7th day of the sexual cycle, the content of total protein, glucose and creatinine increased by 7.1, 11.7 and $11.9 \%(P<0.05)$ respectively, whereas, when intramuscular injection of stimulin-vet, the total protein content increased by $8.3 \%(P<0.05)$, while the activity of aspartate aminotransferase increased by $27.5 \%$ (Gruntkovsky, 2015).

In particular, salts of trace elements that are obtained through the application of nanotechnologies are promising for biological purposes in livestock breeding. It is known that the assimilation of trace elements is more dependent on their chemical compound than on their number (Khomyn \& Fedoruk, 2013). Chelation of nanoparticles of trace elements with water molecules allows them to penetrate through membranes and interact with cell organelles, which creates conditions for manifestations of high biological activity (Nischemenko et al, 2018). The ions of metals themselves are not active, but due to their nano-hydrated cover, they are easily adsorbed, transported in the bloodstream and penetrate through the membranes of cells, easily liberating from the ligands, which creates conditions for their high activity in their locations (Havturina \& Bomko 2015). Some of the above-mentioned drugs include Copper Citrate. The specified trace element is not accidental in the composition of drugs, as Copper plays an important role in the biosynthesis of hormones and vitamins, participates in the regulation of water and gas-energy metabolism, increases the detoxification of liver function (Martson \& Kornuta, 2005). It enhances the use of tissues of vitamins $\mathrm{E}$ and $\mathrm{K}$, activates the action of insulin and inhibits the action of adrenaline, stimulates the activity of hormones of the pituitary gland, eliminates the toxic effects of thyroxine (Letters, 1964).

In addition, Copper plays an important role in the reproduction of animals and acts at the level of the hypothalamus. It is irreplaceable for the growth and development of the animal organism during the embryonic and postnatal periods of ontogenesis, as well as during pregnancy and lactation. In the process of fetal development, Copper is accumulated. The embryo depends entirely on the intake of this trace element from the parent organism, and its increase is partially due to a decrease in the bipolar excretion of Copper (Harris, 2000). Particularly intense accumulation of Copper is observed from the 2nd to the 9th months of pregnancy. High concentration of trace elements in tissues in the early stages of embryonic development is due to the high level of synthetic processes that provide energy and growth of tissues and organs (Martson \& Kornuta, 2005). It was investigated that Copper, actively used for the development of the fetus, is delivered principally by ceruloplasmin (Letters, 1964). It has been proven that the concentration of Copper and ceruloplasmin (Copper - binding protein) increases significantly during pregnancy. The embryo stores almost ten times the size of Copper per unit body weight than the adult body (Harris, 2000). The deficiency of this trace element during pregnancy leads to the death of the embryo, a high percentage of cases of uterine anomalies of the internal organs (heart defects, anomalies of blood vessels), growth disturbances and fetal hemopoiesis (Martson \& Kornuta, 2005). 
One of the least investigated biotechnological drugs is nanovulin-R, which, in addition to Copper Citrate, includes L-arginine. L-arginine is an amino acid that serves as a substrate for the synthesis of Nitrogene Oxide (NO) to form L-citrulline. As a precursor of nitrogene oxide, it plays a vital role in the metabolism and reproduction of animals. It is known that a large amount of L-arginine is present in the allantois fluid of the pig, indicating the role of this aminoacid in the placental nutrition. In addition, L-arginine supplements increase the reproductive capacity of rats, pigs, and mice, and recently it has been studied that amino acid supplements have increased the number of implanted embryos in mice, indicating the effect of L-arginine on the level of endometrium (Saevre, 2016). The endometrium of many species of mammals, including sheep, pigs, mice, rats and humans, due to the presence of arginase, is able to catalyze L-arginine. Arginine is often thought to be the most hydrophilic of 20 essential amino acids. The function of this amino acid in membrane proteins, and even its presence in the hydrocarbon zone of the membrane, raises many questions unanswered.

In connection with the above, when creating biotechnological drugs on the basis of new dietary supplements, one of the main tasks is to find out the interaction of these compounds with cell membranes and the mechanisms of penetration of compounds into living cells. Therefore, knowledge of the primary mechanisms of membranotropic action of the investigated substances will contribute to both the prediction of the consequences of their practical application for farm animals, and the search and development of more effective combinations thereof in biologically active drugs.
The purpose of the study was to determine the concentration effects and primary mechanisms of membranotropic influence of Sodium Glutaminate and its complexes with edible acids (Sodium Succinate, Citric acid, L-arginine) and citrate nanoparticles of Copper (Borisevich \& Kaplunenko, 2012) in the range of physiological concentrations of the active substance on the structural- functional state of the lipid matrix of cell membranes.

To achieve the goal, the following tasks were identified: to investigate the concentration effects of Sodium Glutaminate and its complexes on the degree of polarity of the microsurround of the RIII pyrene in monolamellar liposomes from azolectin in the range of concentrations of Sodium Glutaminate 10-510-9 $\mathrm{M}$; to investigate the concentration effects of Sodium Glutaminate and its compositions on the degree of excimerization of $\mathrm{N}$ pyrene in monolamellar liposomes from azolectin in the range of concentrations of Sodium Glutaminate 10-5-10-9 M; to conduct a comparative analysis of the obtained concentration dependences of the influence of Sodium Glutaminate and its complexes on the structure of azolectinic liposomes.

\section{Material and methods.}

The following materials and reagents were used in the research (Table 1). A suspension of monolamellar liposomes $(0.1 \mathrm{mg} / \mathrm{ml})$ was obtained by ultrasonically processing the emulsion of azolectin (n-decane) / $0.1 \mathrm{M}$ $\mathrm{KCl}$ on UZDN-1, U-42 (current at the anode was $0.4 \mathrm{~A}$, frequency - $22 \mathrm{kHz}$ ) for 15 minutes at intensive heat removal. To eliminate structural defects in liposomes, the resulting suspension was maintained for 35 minutes at a tempera- 
ture of $50 \pm 2^{\circ} \mathrm{C}$ and stored at $36 \pm 1^{\circ}$ C. The polydispersion of the liposomal fraction was monitored visually using a binocular microscope ST60-24B2 with an eyepiece micrometer attachment. As a result, a visually homogeneous slurry of liposomes was obtained with an average diameter $\varnothing 0.32 \pm 0.08 \mu \mathrm{m}$.

The structural state of lipid bilayer membranes was evaluated using a fluorescence probe pyrene (Dobretsov, 1989; Ivkov \& Berestovsky, 1981), which is localized in the hydrophobic zone of the fatty acid chains of phospholipids. The fluorescence spectrum of the pyrene has a vibronic structure and is characterized by five peaks of the fluorescence of the probe monomers and one peak of the emission of the excimers (Fig. 1).

The relative intensity of the vibronic bands reflects the degree of polarity of the microsurround of the pyrene. The degree of polarity is RIII = II / IIII, where II is the intensity of the first peak $(373 \mathrm{~nm})$, and IIII is the intensity of the third peak $(384 \mathrm{~nm})$. The microspinity of the phospholipid environment was determined by the degree of excimerization of the pyrene $N(\mathrm{~N}=F E$ / $F M$, where $F E$ is the fluorescence intensity of the pyrene excimer $(\lambda \max 470$ $\mathrm{nm}$ ), and the $F M$ monomers ( $\lambda \max 394$ $\mathrm{nm})$ ). at $\lambda \mathrm{zb} 336 \mathrm{~nm}$.

To $0.8 \mathrm{ml}$ of a suspension of liposome was added $0.1 \mathrm{ml}$ of a pyrene alcohol solution (final concentration of 4 $\mu \mathrm{M})$ and $0.1 \mathrm{ml}$ of the test substance solution (final concentration 10-9, 108, 10-7, 10-6 and 10- $5 \mathrm{M}$ ). After 15 minutes of incubation at $36 \pm 1^{\circ} \mathrm{C}$, fluorescence spectra were recorded. Fluorescence studies were performed on the spectrofluorometer СДЛ-2 (Ukraine).

\section{Substances used for the research}

\begin{tabular}{|c|c|c|c|}
\hline Substance (drug) & Chemical composition & The original form & Degree of purity \\
\hline azolectin & total fraction of soy phospholipids & not lyophilized & C.V.P. \\
\hline pyrene & - & $96 \%$, crystal, & C.V.P. \\
\hline ethanol & - & $98 \%$, liquid & HPLC \\
\hline n-decane & - & liquid & C.V.P. \\
\hline $\mathrm{KCl}$ & - & crystal. & C.V.P. \\
\hline $\mathrm{NaCl}$ & - & crystal. & C.V.P. \\
\hline saline & $\mathrm{NaCl}$ & $\begin{array}{c}0,9 \% \text {, aqueous } \\
\text { solution }\end{array}$ & C.V.P. \\
\hline glutam $1 \mathrm{M}^{*}$ & Sodium Glutaminate & $9,0 \mathrm{mg} / \mathrm{ml}$ & C.P. \\
\hline \multirow{2}{*}{ stymulin* } & \multirow{2}{*}{$\begin{array}{l}\text { Sodium Glutaminate } \\
\text { Sodium Succinate }\end{array}$} & $7,5 \mathrm{mg} / \mathrm{ml}$ & C.P. \\
\hline & & $7,5 \mathrm{mg} / \mathrm{ml}$ & C.P. \\
\hline \multirow{3}{*}{ nanovulin-VHR* } & \multirow{3}{*}{$\begin{array}{c}\text { Sodium Glutaminate } \\
\text { Sodium Succinate } \\
\text { Copper Citrate / Citric acid / Cu }\end{array}$} & $7,5 \mathrm{mg} / \mathrm{ml}$ & C.P. \\
\hline & & $7,5 \mathrm{mg} / \mathrm{ml}$ & C.P. \\
\hline & & $22,5 \mathrm{mg} / \mathrm{ml}$ & C.P. \\
\hline \multirow{4}{*}{ nanovulin- $\mathrm{R} *$} & \multirow{4}{*}{$\begin{array}{c}\text { Sodium Glutaminate } \\
\text { Sodium Succinate } \\
\text { L-arginine } \\
\text { Copper Citrate / Citric acid / Cu }\end{array}$} & $7,5 \mathrm{mg} / \mathrm{ml}$ & C.P. \\
\hline & & $7,5 \mathrm{mg} / \mathrm{ml}$ & C.P. \\
\hline & & $1,0 \mathrm{mg} / \mathrm{ml}$ & C.P. \\
\hline & & $22,5 \mathrm{mg} / \mathrm{ml}$ & C.P. \\
\hline
\end{tabular}

Note: $*$ - drugs in saliva 


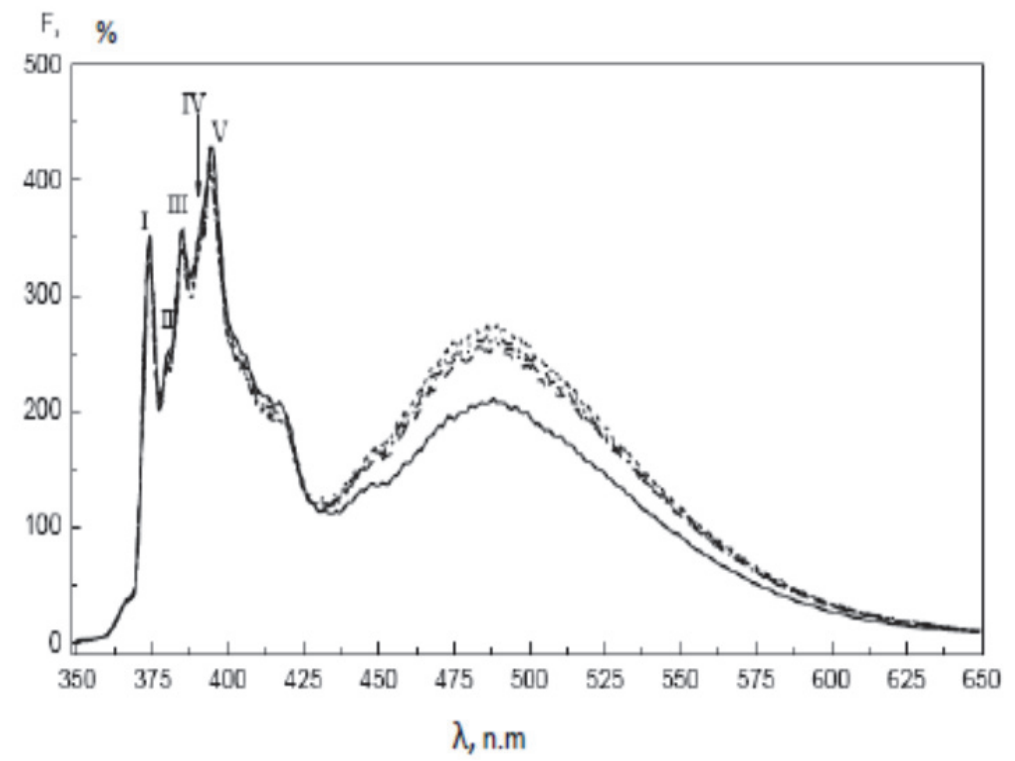

Fig. 1. Spectros of the fluorescence of the pyrene in the liposomes. I, II, III, IV, V - vibronic peaks of pyrene monomers. (Ivkov \& Berestovsky, 1981)

The results of experimental studies were processed using conventional methods of variation statistics.

\section{Results and discussion.}

The incubation of monolamellar azolectinic liposomes with the preparation of glutam $1 \mathrm{M}$ at concentrations of 10-9, 10-8, 10-7, 10-6, and 10-5 M of the active substance, Sodium Glutaminate, led to changes in the vibronic structure of the fluorescence spectrum of the pyrene, its polarity and microcosmity molecular microsurround (Fig. 2), which testifies to the membranotropic nature of the effect of the drug.

Sodium Glutaminate at concentrations of 10-9-10-7 M leads to an increase in the relative intensity of the right-side band III, indicating a change in the transversal distribution of pyrene monomers in the hydrophobic zone of lipid bilayer and an increase in its polarity. The in- crease of the RIII value, depending on the dose, is linear (the maximum of RIII relative to the control was $+4.1 \%$ at the action of Sodium Glutaminate at a concentration of 10-7 M) (Fig. 2a). However, under the action of Sodium Glutaminate in concentrations of 10-6 and 10-5 $\mathrm{M}$, the nature of the membranotropic effect of the drug varied. In the range of concentrations of Sodium Glutaminate 10-6-10-5 M, a linear decrease in the value of the RIII index was observed (with a $10-5$ M RIII $-2.74 \%$ relative to control values). The regression analysis of the concentration dependence of Sodium Glutaminate-induced changes in the polarity of the hydrophobic zone of lipid bilayer showed that the process has a biaxial nature with a point of fracture of 10-7 M. At the same time, it was shown that the influence of Sodium Glutaminate in the limits of the investigated concentrations led to an exponential increase in the rate of excimerization of the pyrene 


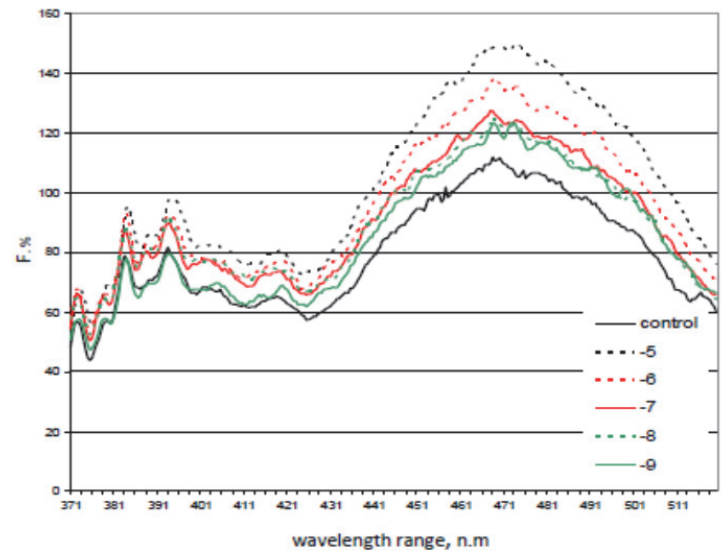

Fig. 2. Changes in the intensity of the fluorescence of the pyrene, parameters RIII (a) and N (b) in monolamellar azolectinic liposomes modified by the drug of glutam $1 \mathrm{M}$ in the concentration range 10-9-10-5 $\mathrm{M}$

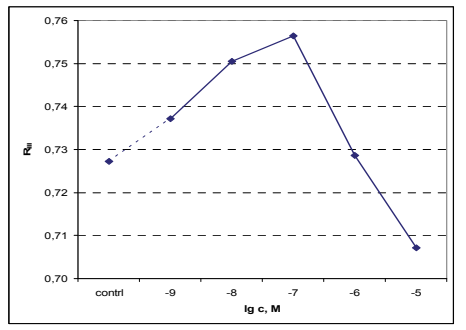

a

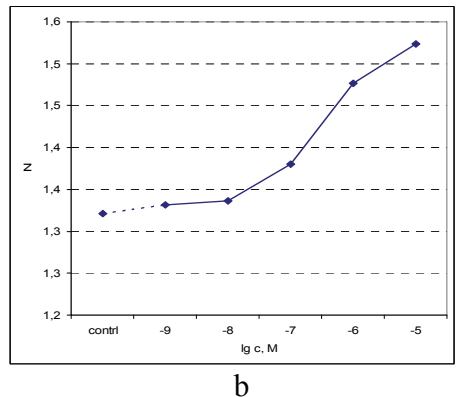

$\mathrm{N}$ (Fig. 2 b). The growth of the pyrene $\mathrm{N}$ as a factor in the lateral distribution of the pyrene indicates an increase in the free volume in the lipid bilayer in the formation of Sodium Glutaminate complexes with liposomes, which is the result of embedding of Sodium Glutaminate molecules into lipid bilayer and decreasing the packing density of lipid molecules (destructive effect). The last statement suggests that the two-stage nature of the concentration-dependent influence of Sodium Glutaminate on the polarity of the hydrophobic zone of the membrane is the result of the competitive interaction of two elementary processes, the intercalation of Sodium Glutaminate molecules into the hydrophobic zone of lipid bilayer and the sealing of surface charges that inhibits this process.

Individual membranotropic effects of Sodium Glutaminate undergo a certain modification while co-administration of this substance with Sodium Succinate.

The integral effect of Sodium Glutaminate / Sodium Succinate complex (stimulin preparation) on the polarity of the lipid microsrround of the pyrene already at a concentration of $10-9 \mathrm{M}$ resulted in an increase in the RIII (+5.7\%) increase in comparison with the individual effects of Sodium Glutamate. However, a further increase in the concentration of the drug resulted in a gradual decrease in this parameter (RIII $+4.3 \%$ during the action of Sodium Glutaminate / Sodium Succinate 10-5 M). Simultaneously, the effect of the drug on the microcosmity of lipids at concentrations of 10-9 $\mathrm{M}$ was characterized by parameters of the parameter $\mathrm{N}$ smaller than the control, indicating the imposition of general membranotropic effects of Sodium Glutaminate on the membrane-stabilizing Sodium Succinate effect. A further increase in the concentration of the drug resulted in a linear increase in the microvascularity of the hydrophobic zone of lipid bilayer. We assume that the elementary mechanisms that underlie these membranotropic effects are similar to those described above (with correction 
for the membrane-stabilizing effect of Sodium Succinate).

Recently, the attention of many researchers is attached to the idea of application in combination with the already known dietary supplements' nanomaterials of different etiologies. The unique individual physical and chemical properties of the latter in complex using can significantly modify the medical and biological effects of traditional drugs. Therefore, the next step of our research is to determine the integral effects of simultaneous effects on the structure of bicarbonate lipid membranes of Sodium Glutaminate / edible acid / Copper Citrate compositions.

The modification of the asolectin monolamellar liposomes with drug nanovulin-VHR (Fig. 3) at concentrations of 10-9 M resulted in a sharp increase in the polarity of the microsurround of the pyrene $(+7.2 \%)$, followed by a linear decrease in the value of this index to the control values in the range of concentrations of 10-9 -10 -5 M (Fig. 3a).
At the same time, throughout the studied range of concentrations of nanovulin-VHR did not significantly affect the microcosmity of lipid bilayer (Fig. 3b). Thus, it can be assumed that Copper Citrate, in combination with Sodium Glutaminate and Succinate, virtually eliminates both the membrane-stabilizing and membrane-disruptive effects of their influence on the structure of lipid packing in bilayer. It should be noted that in the experiments with Copper Citrate at concentrations of 10-6-10-5 $\mathrm{M}$ of nanovuline-VHR there was also observed a general quenching of the pyrene fluorescence, which could be known as the fact of the penetration of aquachelates into the hydrophobic zone of lipid bilayer.

Introduction to the studied complex of substances L-arginine (nanovulin-R) led to the modification of its membranotropic properties (Fig. 4).

First, with the application of the drug at a concentration of 10-9 M, there was a general quenching of the pyrene

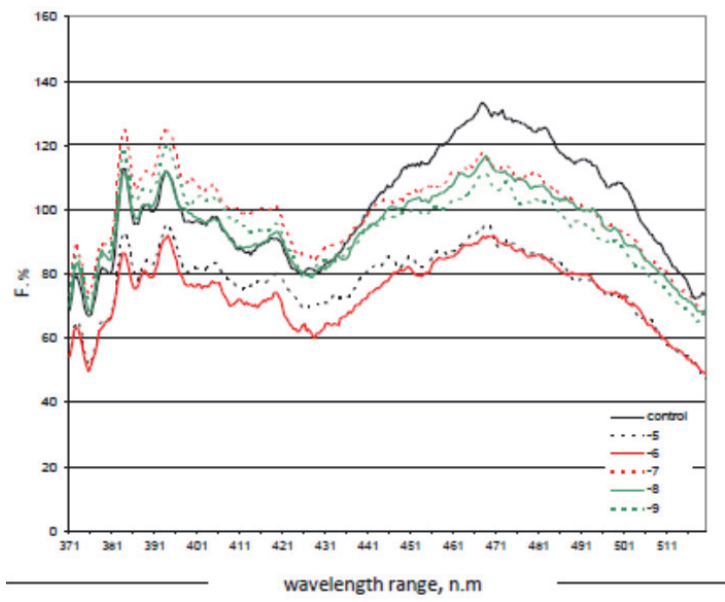

Fig. 3. Changes in the intensity of the fluorescence of the pyrene, parameters RIII (a) and N (b) in monolamellar asolectin liposomes modified by the drug nanovulin-VHR at a concentration of 10-9-10-5 M

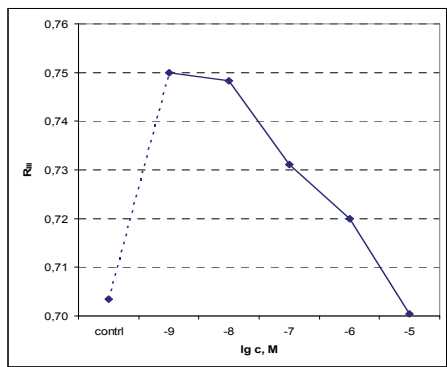

a

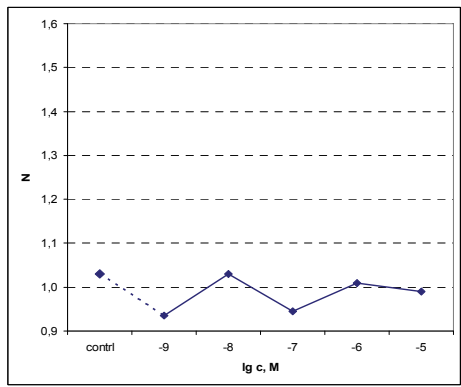

b 

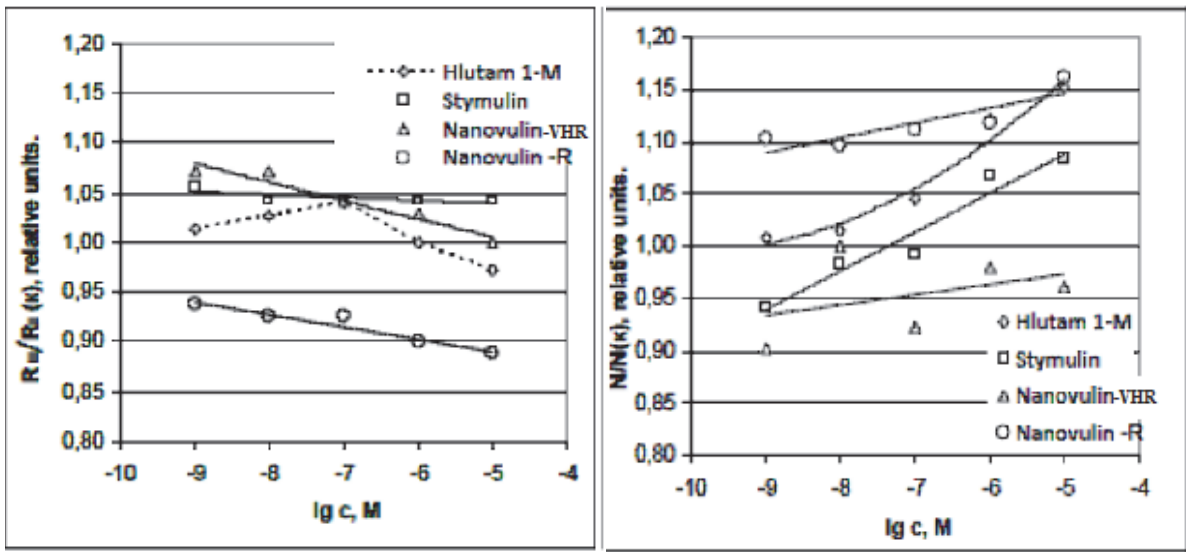

Fig. 4. Results of regression analysis of relative changes in the degree of polarization (a) and excimerization (b) of the pyrene in azolectin monolamellar liposomes under the action of the investigational drugs in the range of concentrations 10-9-10-5M

fluorescence, which may indicate an increase in the degree of permeability of the hydrophobic zone of the membrane to Copper Citrate. Secondly, there was a sharp linear decrease of the parameter RIII (nanovolin-R 10-9 M -7,32\%, 10-5 M - 12,21\%), which indicates an increase in the density of charges in the upper layers of the lipid bilayer due to the incorporation of the drug components. In the favor of the growth of a charge density, the highest level of influence of nanovulin- $\mathrm{R}$ on the microvessel of the lipid membrane (10-9 M + 10.29\%, $10-5 \mathrm{M}+16.18 \%$ ) is among the highest in a number of investigated drugs. Thus, it can be assumed that the presence of L-arginine increases the permeability of lipid bilayer to all other ingredients of arginine and intensifies the development of destructive effects on the packaging of lipids in the membrane.

\section{Conclusions}

1. Sodium Glutaminate, when used in conjunction with a lipid bilayer membrane, exhibits a low-intensity membranotropic effect on its structure. In case of penetrating into the hydrophobic zone of the membrane, it increases the polarity of the lipid environment and forms structural defects, which lead to an increase in the microcosmity of the lipid bilayer and the density of charges on its surface.

2. Sodium Succinate is characterized by a membrane-stabilizing effect. Its consistent use with Sodium Glutaminate reduces the destructive effect of the latter on the lipid membrane.

3. Complex application of Sodium Glutaminate and Succinate with Cuprum Citrate leads to a mutual leveling of membranotropic effects of influence.

4. Adding to the complex L-arginine, on the contrary, leads to an increase in destructive effects on the lipid bilayer of all components of the complex, due to the possible overall increase in permeability of the lipid bilayer.

5. The obtained results create preconditions for the improvement of drugs of non-hormonal origin, which allow physiological functions of farm animals correcting and are safe for consumers of livestock products. 


\section{References}

1. Borisevich, V., Kaplunenko, V. (2012). Nanomaterials and nanotechnologies in veterinary practice. VD "Advitsenna", Kyiv.

2. Bychko, A., Sokolova, V., Prylutska, S., Bogutska, K., Rybalchenko, V., Evstigneev, M., Prylutskyy, Y., Epple, M., Ritter, U., Scharff, P. (2016). Interaction of C60 fullerene complexed to cisplatin with model bilipid membranes and its uptake by HeLa cells. Mat.wiss. u. Werkstofftech. 47(2-3). 105-111.

3. Dobretsov, G. (1989). Fluorescent probes in the study of cells, membranes and lipoproteins. "Science". Moscow.

4. Gennis, R. (1997). Biomembranes: Molecular Structure and Function. "Peace". Moscow.

5. Greene, M., Feugang, M.,Pfeiffer, E., Stokes, V., Bowers, D. Ryan, L. (2012). L-arginine Enhances Cell Proliferation and Reduces Apoptosis in Human Endometrial Cells. Biology of Reproduction. 87. 471-480.

6. Gruntkovsky, M. S. (2015). Biotechnological method of stimulation of reproductive ability of cows by neurotropical and metabolic preparations. The dissertation author's abstract. Bila Tserkva.

7. Gruntkovsky, M. S., Sheremeta, V. I. Kaplunenko, V. G. (2015). Reproductive ability of cows using drug nanovulin-vhr. Animal Breeding and Genetics. 49. 199-203.

8. Harris, E. (2000). Cellular copper transport and metabolism. Annu. Rev. Nutr. 20. 291310.

9. Havturina, A., Bomko, V. (2015). Influence of organic microelements complex Bioplex $^{\circledR}$ on Holstein cows performance. Bulletin of Sumy NAU. 2(27). 152-155.

10. Ivkov, V., Berestovsky, G. (1981). Dynamic structure of lipid bilayer. "Science". Moscow.

11. Khomyn, M. M., Fedoruk, R. S. (2013). Antioxidant profile of organism and biological value of milk of cows in the first months of lactation under feeding by chromium and selenium citrate. The Animal Biology. 15(2). 141-148.

12. Kositsyn, N., Sapetsky, A., Mosharova, I. (2004). General physiological mechanisms of gluta- mate action on the central nervous system. Advances in Physiological Sciences. 1. 20-42.

13. Kukhar, V., Luik, A., Mogilevich, S. (1992). Chemistry of bioregulatory processes. Scientific Opinion, Kyiv.

14. Lancey, R., Lee, S. (1993). Ceruloplasmin and copper transport during the latter part of gestation in the rat. Proc Soc Exp Biol Med. 203(4). 428-439.

15. Letters, R. (1964). The application of a two-dimensional paper-chromatographic technique to the analysis of phospholipids. Biochemical J. 93(2). 313-316.

16. Martson, L., Kornuta, N. (2005). The role of copper in the process of embryonic development. Modern Problems of Toxicology. 2. 34-38.

17. Nischemenko, N. P., Trokoz, V. O., Poroshynska, O. A, Stovbecka, L. S., Emelynenko, A. V., Emelynenko, A. A. (2018). The influence of nanoaquachelates of selenium, germanium and their complex on the embryonic development of quails. Fiziol. Zh., 64, 3, 30-36.

18. Ostrovska, G. (2004). Primary mechanisms of membrane modulating action of bioregulators of nature and synthetic origine. Dissertation for scientific degree of doctor the biological sciences 03.00.02 - biophysics, Kyiv.

19. Prylutskyy, Yu., Bychko, A., Sokolova, V., Prylutska, S., Evstigneev, M., Rybalchenko, V., Epple, M., Scharff, P. (2016). Interaction of 660 fullerene complexed to doxorubicin withmodel bilipid membranes and its uptake by HeLa cells. Materials Science \& Engineering C-Materials for Biological Applications. 59. 398-403.

20. Rybalchenko, V., Ostrovskaya, G. (1998). Lipid pathway of chemical intercellular signaling system, glutamic acid. XIX mendeleev's congress on general and applied chemistry. Report theses. 1. 124.

21. Rybalchenko, V., Ostrovskaya, G., Rybalchenko, T. (1999). The role of lipids in the reception of chemical information signals glutamine natriyu. Inform.at nonagent.med. 1. 78-79.

22. Saevre, C. B., Meyer, A. M., Van Emon, M. L., Redmer, D. A., Caton, J. S., Kirsch, J. D., 
Luther, J.S., Schauer C.S. (2016). Impacts of arginine on ovarian function and reproductive performance at the time of maternal recognition of pregnancy in ewes. Journal of Animal Science. 94(8). 13-16.

23. Seba, M. V. (2005). Fertilization of heifers of black-and-white milk breeding after the introduction of biologically active drugs. Scientific herald of the National Agrarian University. 85. 165-166.

24. Sheremeta, V. I., Bezverha, L. N., Seba M.V., Trohymenko V.Z. (2017). Reproduction func- tion of females increases after injection of neurotrophic metabolic substances glutam 1M. Fiziologichnyi Zhurnal. 63(4), 72-79.

25. Sheremeta, V. I., Seba, M. V. (2004). The content of sex hormones in the blood of Ukrainian heifers black-and-white dairy breed. Journal of Agrarian Science. 12. 35-38.

26. Tishchenko, Y., Sheremeta, V. (2006). The reproductive function of cows when introducing a biologically active drug in the postnatal period. Bulletin of Dnipropetrovsk State Agrarian University. 2. 92-94.

М. В. Себа, М. О. Хоменко, Д. К. Носевич, М. І. Голубєв, В. Г. Каплуненко, І. В. БєлінСьКа, В. К. РИбальченко (2020). ВПЛИВ НЕЙРОТРОПНОМЕТАБОЛІЧНИХ ПРЕПАРАТІВ НА СТРУКТУРНО-ФУНКЦІОНАЛЬНИЙ СТАН ЛІПІДНОГО МАТРИКСУ КЛІТИННИХ МЕМБРАН. АNIMAL SCIENCE AND FOOD TECHNOLOGY, 11(3): 50-61. https://doi.org/10.31548/animal2020.03.056.

Анотація. Останім часом, все частіше для стимуляції репродуктивної функції тварин, застосовують біотехнологічні препарати, які створені на основі нейротропно-метаболічних сполук та мікроелементів нанобіотехнологічного походження. Для пошуку і розробки нових біотехнологічних препаратів та для більш ефективних і безпечних комбіначій в них біологічно активних речовин необхідно знати біохімічні механізми мембранотропної дії цих речовин на клітину. Оскільки чі речовини в залежності від дози та періоду дії можуть приводити до фізіологічних змін у клітині та ініціювати неспецирічні токсичні ефректи на організм тварин. У статті представлені результати досліджень впливу складових препаратів нейротропно-метаболічної дії на структурно-функціональний стан ліпідного матриксу клітинних мембран. У досліді використовували чотири препарати: глютам 1М (глутамінат натрію), стимулін (глутамінат натрію, сукцинат натрію), нановулін (глутамінат натрію, сукцинат натрію, цитрат Cu), нановулін-R (әлутамінат натрію, сукцинат натрію, L-аргінін, цитрат Cu). Перед нами стояло завдання дослідити концентраційні ефректи та первинні механізми мембранотропного впливу складових досліджуваних препаратів у діапазоні фізіологічних концентрацій діючої речовини на структурно-функціональний стан ліпідного матриксу клітинних мембран. За результатами досліджень було встановлено, що глутамінат натрію, який входить до складу усіх досліджуваних препаратів, впливає на полярність гідрофобної зони мембрани та підвищує полярність ліпідного оточення. Тоді, як застосування його з сукцинатом в одному препараті (стимулін, нановулін, аргінін) зменшує деструктивний вплив глутамінату натрію на ліпідну мембрану клітин. Також, слід зазначити, що аквахелат купруму в комплексі з глутамінатом та сукцинатом натрію (нановулін, нановулін-R) практично нівелює мемраностабілізуючі та мембранодеструктивні ефекти їх впливу на структуру пакування ліпідів у бішарі. $з$ результатів досліджень нановуліну можна припустити, що аквахелати проникають до гідрофобної зони ліпідного бішару, про що свідчить загальне гасіння флуоресценції пірену.

Ключові слова: глутамінат, сукцинат, нановулін, купрум, мембрани, аквахелати. 